\title{
An Evaluation of the Self-Regulation of Promotional Competitions in South Africa
}

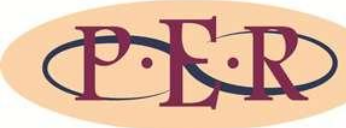

Author

DP Strachan

Affiliation

University of Pretoria, South Africa

Email danie.strachan@gmail.com

Date published 3 June 2016

Editor Prof C Rautenbach

How to cite this article

Strachan DP "An Evaluation of the Self-Regulation of Promotinal Competitions in South Africa" PER / PELJ 2016(19) - DOI http://dx.doi.org/10.17159/17273781/2016/v19i0a730

Copyright

\section{cc) (i)}

This work is licensed under a Creative Commons Attribution 4.0 International License.

DOI

http://dx.doi.org/10.17159/17273781/2016/v19i0a730

\begin{abstract}
Promotional competitions are competitions in which prizes are awarded by lot or chance in order to promote goods or services. In order to protect participants and consumers against abuse, these competitions are usually regulated by gambling or consumer protection legislation. However, the relevant legislation is often complemented by self-regulation, which is the focus of this contribution.
\end{abstract}

Self-regulation entails the regulation or governing of an industry by the role players in that industry. This article commences by explaining the relevant terminology and exploring self-regulation in general, including the various forms of self-regulation and the binding force thereof. The nature of self-regulation is discussed together with the advantages and challenges associated with this form of regulation. This is followed by some examples of self-regulation on a global level in order to provide a comparative perspective on the topic. The provisions of the International Chamber of Commerce's Consolidated Code of Advertising and Marketing Communications Practice are summarised and the European Advertising Standards Alliance's role in self-regulation is considered. Attention is also given to the relevant industry codes in the United Kingdom in view of the comprehensive way in which promotional competitions are covered by selfregulation in that country.

The main part of the article centres on the self-regulatory position in South Africa. A brief overview of the role and function of the Advertising Standards Authority of South Africa (ASASA) is provided. The provisions of the ASASA's Code of Advertising Practice are then examined and some ASASA rulings are discussed in order to illustrate the relevant principles. Thereafter, the focus shifts to the Code of Conduct of the Wireless Application Service Providers' Association, which contains detailed provisions relating to promotional competitions. Some relevant rulings are also considered. In conclusion, comments are made regarding the current state of the self-regulation of promotional competitions in South Africa.

\section{Keywords}

Promotional competitions; prize competitions; consumer protection; selfregulation; advertising; sales promotion; ICC Consolidated Code of Advertising and Marketing Communications Practice; European Advertising Standards Alliance; Code of Non-Broadcast Advertising, Sales Promotion and Direct Marketing; Code of Advertising Practice of the Advertising Standards Authority of South Africa; Code of Conduct of the Wireless Application Service Providers' Association. 


\section{Introduction}

Marketers employ various tools in order to grow businesses and increase sales. These include advertising, direct marketing and sales promotion activities. ${ }^{1}$ There are various forms of sales promotion activities, but only one of them will feature in this article: the prize promotion. This form of sales promotion involves an activity in which consumers can win a prize. In some prize promotions, winners are selected based on their skill, while in others the outcome is determined by lot or chance (luck). ${ }^{2}$ In South Africa, chance-based prize promotions are known as "promotional competitions", ${ }^{3}$ and these competitions will be the focus of this article.

Promotional competitions are often regulated by legislation in order to protect consumers against abuse. ${ }^{4}$ The statutory regulation is frequently

* DP Strachan. LLB (UP). LLD candidate, Faculty of Law, University of Pretoria. This article is based on parts of the author's LLD thesis, titled The Regulation of Promotional Competitions in South Africa. Email: danie.strachan@gmail.com.

1 Du Plessis "Introduction to Integrated Marketing Communication" 3-7; Koekemoer Advertising and Sales Promotion 4-11; Semenik et al Advertising and Promotion 1314, 22-23; Shimp Integrated Marketing Communication 7-8. Technically, promotional competitions resort under sales promotion instead of advertising. Sales promotion and advertising are separate categories of marketing communication. From a marketing studies perspective, advertising involves a situation where a marketer makes payment in order to spread its message to the public, payment playing an essential role in this definition. (See Semenik et al Advertising and Promotion 11.) However, it seems that advertising can also have a broader meaning, which overlaps with other forms of marketing communication or can even be synonymous with marketing in general. For example, the definition of "advertisement" in the Advertising Standards Authority of South Africa's Code of Advertising Practice (ASA Code) includes any communication "which is intended to promote the sale, leasing or use of any goods or services", and states that the "[p]romotional content of display material, menus, labels, and packaging also fall within the definition" (para 4.1 of the ASA Code.) Also see the definition of "advertisement" in the Consumer Protection Act 68 of 2008 (CPA), which is somewhat similar to the one in the ASA Code (s 1 of the CPA.) The definitions in the CPA and ASA Code encapsulate matters and communication forms that do not fall within marketing studies' narrow definition of "advertising", and do not refer to payment or consideration. (See Schimmel Advertising Law 48.) However, since the principal regulation of promotional competitions in South Africa is found in the CPA and ASA Code, this topic will be discussed within the broad meaning of "advertising", although these competitions are, technically, not advertising but actually sales promotion tools.

2 Bennett 2007 Practical Lawyer 39-40.

3 See $\mathrm{s} 36(1)(\mathrm{d})$ of the CPA.

4 In South Africa, promotional competitions are currently regulated by s 36 of the CPA and regulation 11 of the Consumer Protection Regulations. Before the CPA came into force, s 54 of the Lotteries Act 57 of 1997 contained the requirements for the lawful operation of promotional competitions in South Africa. Since this article's focus is on the self-regulation of such competitions, the CPA's provisions will not be analysed here. For a discussion of the statutory provisions, see for example De Stadler Consumer Law Unlocked 66-78; Taylor 2011 Without Prejudice 17-20; Van Eeden Consumer Protection Law 169-174; Van Heerden "Section 36". Regarding 
complemented by self-regulation in the form of industry codes. ${ }^{5}$ The purpose of this article is to consider the self-regulation of promotional competitions in South Africa. This evaluation commences with a discussion of self-regulation in general in order to explore the unique nature of this form of regulation, including the advantages and disadvantages attached to it. This is followed by an examination of the self-regulation of promotional competitions on an international level. South African businesses can consider the provisions of international codes in order to identify best practice in relation to the conducting of promotional competitions. The international codes can also influence the drafting of industry codes in South Africa. The focus then shifts to a detailed analysis of the self-regulatory position in South Africa.

\section{Self-regulation in general}

Self-regulation entails the regulation or governing of an industry by the role players in that industry. ${ }^{6}$ It is a type of "decentred regulation", ${ }^{7}$ based on the notion that governments should not have the sole role in regulation. ${ }^{8}$ It should not be regarded as "an imperfect substitute for government regulation", but could be viewed as a form of regulation in its own right. ${ }^{9}$ Self-regulation can relate to a variety of subject matters, such as health, product safety, the environment, marketing, advertising and privacy. ${ }^{10}$

Self-regulation can take on many forms, but broadly one can distinguish between voluntary self-regulation and self-regulation that is backed up by legislation. ${ }^{11}$ It could be regarded as "co-regulation", which was developed by an industry in order to avoid government regulation, but could also be created as a result of government's pressure on or directive to an

the need for consumer protection legislation, see De Stadler Consumer Law Unlocked 1-2; Van Eeden Consumer Protection Law 1-5; Woker 2010 Obiter 217231.

5 Woker 2010 Obiter 221-223; Melville and Yeates "Section 82" paras 2-3; De Stadler Consumer Law Unlocked 93-94, 182.

$6 \quad$ Black 1996 MLR 25-28; Black 2001 CLP 116; Gunningham and Rees 1997 L\&P 364; Ramsay Consumer Law and Policy 115-116; Schimmel Advertising Law 5; Ogus 1995 OJLS 97-108; Baldwin, Cave and Lodge Understanding Regulation 136137. According to Boddewyn, self-regulation can refer to an organisation's internal regulation or to the regulation of various organisations that form part of an industry, but this discussion will centre on the self-regulation of a group of organisations in an industry (Boddewyn 1989 Journal of Advertising 20).

Black 2001 CLP 105-112; Black 2002 AJLP 34.

Black 2001 CLP 103-104.

Ramsay Consumer Law and Policy 116.

Gunningham and Rees 1997 L\&P 365.

Melville and Yeates "Section 82" para 3. 
industry. ${ }^{12}$ While some authors explain that self-regulation is often developed as a result of "soft law" - which can consist of guidelines, directives and communications issued by a government ${ }^{13}$ - others regard self-regulation itself as a form of soft law. ${ }^{14}$

The binding force of self-regulation can vary. For example, the provisions of an industry code might be binding only on the members of a voluntary industry organisation that adopted the code. ${ }^{15}$ However, legislation could make an industry code binding on all members of the relevant industry as well. ${ }^{16}$ An example of this would be an industry code that has been accredited in terms of the provisions of the CPA. ${ }^{17}$

Self-regulation, and industry codes in particular, can have the benefit of amplifying consumer protection legislation and providing specific guidance in a particular industry. ${ }^{18}$ It is easier to update such a code on a continuous basis, and the involvement of industry experts usually leads to better industry standards. ${ }^{19}$ It is also more practical to put in place and enforce industry self-regulation, which is not burdened by the formalities associated with government legislation. ${ }^{20}$ Furthermore, self-regulation provides an opportunity for corporations and their critics to collaborate. ${ }^{21}$ It can develop consumers' trust in an industry and make an industry more credible. ${ }^{22}$ In an advertising context, Boddewyn explains that selfregulation can be very effective because advertising takes place in the public eye and is therefore subject to public scrutiny and practical

12 Black 2001 CLP 118. Black mentions that co-regulation may be explained as "regulation in the shadow of the law". Also see Gunningham and Rees 1997 L\&P 366; and Senden 2005 http://bit.ly/1Ore1Dh 11, who refers to the Interinstitutional Agreement on Better Law-Making Concluded between the European Parliament, the Council of Europe and the European Commission, 2003/C321/01 (2003).

13 Senden 2005 http://bit.ly/1Ore1Dh 22.

14 Ramsay Consumer Law and Policy 115.

15 Baldwin, Cave and Lodge Understanding Regulation 139; Ogus 1995 OJLS 100.

16 Gunningham and Rees 1997 L\&P 365-366, citing Huyse and Parmentier 1990 JCP 260; Baldwin, Cave and Lodge Understanding Regulation 139; Ogus 1995 OJLS 100.

17 See $\mathrm{s} 82(8)$ of the CPA.

18 Melville and Yeates "Section 82" paras 1-2. Those authors remark that the CPA can be criticised for regulating consumer protection on a "high level principles" basis, instead of prescribing specific rules.

19 Woker 2010 Obiter 223; Gunningham and Rees 1997 L\&P 366.

20 EASA 2009 http://bit.ly/1XaD0w7.

21 See Haufler Public Role for the Private Sector 1.

22 Labarbera 1980 JAR 27. 
sanctions (such as rulings that require the withdrawal of an advertisement or the publication of corrections).$^{23}$

However, self-regulation is not without criticism. It can be flawed due to the involvement of and "cosy arrangements" between industry roleplayers. ${ }^{24}$ Without a strong industry body and clear sanctions it can be toothless. ${ }^{25}$ Woker remarks that organisations often ignore sanctions or resign from industry organisations if they are taken to task. ${ }^{26}$ Selfregulation is also weakened by inconsistent enforcement. ${ }^{27}$ In addition, its effect can be questioned if the industry is not transparent and accountable. ${ }^{28}$ Critics remark that "the industry's perceived abuses alienate consumers and conflict with the goal of consumer protection". ${ }^{29}$ Ultimately, the value of self-regulation depends on industry members' compliance with the spirit and letter of the relevant industry codes. ${ }^{30}$

In South Africa, section 82 of the CPA provides for the development of industry codes of conduct and the accreditation of industry ombuds. These industry codes are therefore examples of "sanctioned self-regulation". ${ }^{31}$ Some codes have already been accredited, while others are in progress. ${ }^{32}$ Once a code has been accredited it becomes binding on all suppliers in

Boddewyn 1989 Journal of Advertising 22.

Gunningham and Rees 1997 L\&P 366-367; Haufler Public Role for the Private Sector 2; Melville and Yeates "Section 82" para 10. Melville and Yeates point out that the first version of the Industry Code of Conduct for the Automotive Industry was subject to such criticism (Melville and Yeates "Section 82" para 10 fn 5 and the source cited there.)

Woker 2010 Obiter 222.

Woker 2010 Obiter 222. However, she remarks that South Africa's Advertising Standards Authority seems to be successful due to the buy-in of prominent organisations as well as the existence of effective penalties.

Melville and Yeates "Section 82" para 12; Gunningham and Rees 1997 L\&P 370.

Gunningham and Rees 1997 L\&P 370; Haufler Public Role for the Private Sector 2.

Reader 1995 U Pa.J Int'l Bus L 182.

Boddewyn 1989 Journal of Advertising 21.

Black 2001 CLP 118. Black explains that "sanctioned self-regulation" involves a situation where an industry organisation drafts the code and the government then accredits it.

The Minister of Trade and Industry has prescribed the Automotive Industry Code of Conduct as well as the Consumer Goods and Services Industry Code of Conduct in terms of the CPA's provisions, and the Motor Industry Ombud of South Africa and the Consumer Goods and Services Ombud have respectively been accredited for alternative dispute resolution purposes (see GN 817 in GG 38107 of 17 October 2014 and GN R271 in GG 38637 of 30 March 2015.) A proposed code of conduct and dispute resolution scheme for the advertising industry has been published (see GN 224 in GG 36253 of 22 March 2013.) The Franchise Association of South Africa is also driving a process to establish an ombud and alternative dispute resolution scheme for the franchise industry (Bizcommunity $2013 \mathrm{http}: / /$ bit.ly/24SapOl) A draft industry code of conduct has been published in this regard. See GN 33 in GG 39631 of 29 January 2016. 
the relevant industry, who must adhere to the provisions of the code. ${ }^{33}$ Failure to comply with the provisions of a code can amount to "prohibited conduct" - which can lead to sanctions. ${ }^{34}$

\section{Examples of international advertising self-regulation}

\subsection{The International Chamber of Commerce}

There is an ongoing effort to implement advertising self-regulation on an international level. ${ }^{35}$ The International Advertising Association, and the International Chamber of Commerce (ICC) in particular, have been playing key roles in this endeavour. ${ }^{36}$ The ICC's Commission on Marketing and Advertising bears the responsibility for drafting and revising codes for the marketing and advertising industries. ${ }^{37}$ The ICC's first Code of Advertising was released in 1937. ${ }^{38}$ Self-regulatory organisations in numerous countries have modelled their advertising industry codes on the ICC's Code of Advertising, ${ }^{39}$ and the Code has been described as the "bible of advertising self-regulation". ${ }^{40}$ The latest revised version of the ICC Consolidated Code of Advertising and Marketing Communications Practice ("ICC Code") was published in 2011.41

The ICC Code is merely a self-regulatory code. ${ }^{42}$ It is not binding on any particular person or organisation, and is subordinate to whatever legislation may apply. ${ }^{43}$ The ICC does not publish any rulings relating to the ICC Code, although it might provide guidance on the interpretation of its provisions. ${ }^{44}$ However, the ICC motivates "its adoption and use" on a global basis in order to set "standards of ethical conduct" relating to the "promotion of any kind of goods and services". ${ }^{45}$ A number of organisations apply the ICC Code, for example the Danish Consumer

Section 82(8) of the CPA.

Melville and Yeates "Section 82" para 6; De Stadler Consumer Law Unlocked 182.

Moves to implement international advertising self-regulation started in the $1900 \mathrm{~s}$ when the Associated Advertising Clubs of the World adopted the Truth in Advertising Resolution in 1911. See Ginosar "Regulation of Advertising" 260.

Ginosar "Regulation of Advertising" 260.

ICC 2015 http://bit.ly/1VX1idT.

ICC 2015 http://bit.ly/228Wdz4.

ICC $2015 \mathrm{http}: / /$ bit.ly/228Wdz4.

Boddewyn Advertising Self-Regulation 3, quoted in Verbruggen Transnational Private Regulation 5.

International Chamber of Commerce Consolidated Code (ICC Code).

In other words, it does not have the status of legislation enacted by a parliament.

Verbruggen Transnational Private Regulation xiv; ICC Code 2.

Verbruggen "Enforcement of Transnational Private Regulation" 305; ICC Code art 25.

ICC Code 3-4. 
Ombudsman, ${ }^{46}$ the Swedish Advertising Ombudsman ${ }^{47}$ and the German Advertising Standards Authority. ${ }^{48}$ A number of countries' self-regulatory organisations have also based their advertising industry codes on the ICC Code, including South Africa, Mexico, India and Canada. ${ }^{49}$

Apart from the "General Provisions on Advertising and Marketing Communication Practice" established by it, ${ }^{50}$ the ICC Code contains a chapter which is dedicated to sales promotions. ${ }^{51}$ The chapter regulates various kinds of sales promotions, such as premium offers, price reductions and vouchers. ${ }^{52}$ It defines a prize promotion as "any skill contest or prize draw used in conjunction with a sales promotion activity". 53 Accordingly, the provisions would apply in respect of skill-based contests as well as competitions in which the outcome is determined by chance.

The ICC Code sets out a number of general principles in respect of sales promotions. ${ }^{54}$ These provisions are aimed at ensuring fair and honourable conduct, meeting consumer expectations, prompt and efficient administration, transparent terms and conditions, fair conduct and avoiding anything which is "likely to bring sales promotions into disrepute". ${ }^{55}$ These general principles are followed by some specific provisions. If one applies the specific principles to prize promotions, the ICC Code can be understood to require that all offers relating to prize promotions must be clear and free of exaggeration. ${ }^{56} \mathrm{~A}$ prize promotion must not be marketed in a way which might mislead consumers regarding the "value, nature or the means of participation". ${ }^{57}$ If consumers are required to purchase a product in order to participate in the prize promotion, the promoter must ensure that the availability of those products is sufficient to meet

Article A1 of the ICC Code.

55 See the principles set out in art A1 of the ICC Code.

56 Article A2 of the ICC Code.

57 Article A3 of the ICC Code.

Danish Consumer Ombudsman 2015 http://bit.ly/1V22ED3.

Swedish Advertising Ombudsman About http://bit.ly/1snrgvc. http://bit.ly/1WxZesS.

ICC 2015 http://bit.ly/23QNnW1.

Chapter A (ICC Code 16-22).

ICC Code 16. prize promotions).

German Association of Communications Agencies date unknown

The General Provisions consist of 26 articles that set out general principles relating to matters such as decency (art 2), honesty (art 3), truthfulness (art 5), data protection and privacy (art 19) and environmental behaviour (art 22).

ICC Code 16. Although some provisions are aimed at prize promotions specifically, the provisions relate mostly to all forms of sales promotions (which would include 
anticipated demand..$^{58}$ The relevant promotional items need to be safe and free of hazards. ${ }^{59}$ There are specific provisions that pertain to sales promotion intermediaries as well. ${ }^{60}$

The ICC Code also deals with the information that must be made known to consumers in relation to prize promotions, and prescribes the minimum details that must be disclosed. ${ }^{61}$ This information must include the competition rules, details about any costs of participation (excluding communication costs at or less than standard rates), restrictions on the number of entries, details regarding prizes, the winner selection procedure, the competition's closing date, when and how results will be announced, the winners' tax obligations, when prizes must be collected, and information about how the winners' images or their entries might be used after the competition. ${ }^{62}$

\subsection{The European Advertising Standards Alliance}

The European Advertising Standards Alliance (EASA) promotes selfregulation in the advertising industry on a regional level. ${ }^{63}$ The EASA consists of the self-regulatory organisations that operate in the Alliance's various member countries in addition to members from the advertising industry. ${ }^{64}$ The advertising industry in Europe established the EASA in order to self-regulate advertising and avoid legislation being passed instead. ${ }^{65}$ The EASA does not have its own industry code, and its selfregulatory organisation members typically base their own codes on the ICC Code. ${ }^{66}$ The EASA is also a member of the International Chamber of

Article A4 of the ICC Code. Promoters must be able to prove that they calculated this demand prior to launching the competition. The provisions of s 34(5)(a) of the CPA reflect these requirements as well (in the context of promotional offers).

59 Article A5 of the ICC Code.

60 An "intermediary" is "any person, company or organisation, other than the promoter, engaged in the implementation of any form of sales promotion" (ICC Code 17.) The relevant provisions relate to the information that must be disclosed to intermediaries (art A7), the protection of the interests of intermediaries and their employees (art A8), the timing of deliveries (art A8) and the contractual relationships between intermediaries and their consumers (art A8). Art A9 also sets out intermediaries' obligations in respect of prize promotions.

61 Article $\mathrm{A} 6$ of the ICC Code.

62 See art $A 6$ of the ICC Code for the detailed requirements.

63 EASA date unknown http://bit.ly/1sbV9hq. See De Stadler Consumer Law Unlocked 60.

64 EASA date unknown http://bit.ly/1sbV9hq; Gray 2005 Young Consumers 20. South Africa's Advertising Standards Authority is a non-European corresponding member of EASA (EASA date unknown http://bit.ly/1TTSmT6).

65 Verbruggen Transnational Private Regulation xii; Reader 1995 U Pa.J Int'l Bus L 181-182.

66 Casey and Scott 2011 JLS 93; EASA 2003 http://bit.ly/1ZRISKV 9. 
Commerce and is involved in setting the standards contained in the ICC Code. ${ }^{67}$

The EASA does not function as an umbrella self-regulatory organisation for Europe, ${ }^{68}$ but functions as "the advertising industry's single voice on self-regulation".69 It does, however, coordinate complaints received in respect of advertising across European countries' borders. ${ }^{70} \mathrm{~A}$ consumer in one country can therefore file a complaint against an advertisement with the self-regulatory organisation in the consumer's country, and that organisation will then refer the complaint via the EASA to the selfregulatory organisation in the country where the media platform that carried the advertisement is based. ${ }^{71}$ The EASA also carries out advertising monitoring projects and provides advertising clearance advice. ${ }^{72}$

One of the EASA's aims is to ensure that advertising self-regulation is extended across the European Union. ${ }^{73}$ The EASA publishes an overview of self-regulation in Europe and other countries. ${ }^{74}$ In addition, it issues recommendations and guidelines in respect of self-regulatory codes. Some argue that this creates "a form of delegated regime within the EU", due to the European Commission's involvement in the EASA's issuing of guidelines. $^{75}$ The EASA has also formulated best practice recommendations relating to the operations of self-regulatory organisations that are members of the EASA. ${ }^{76}$ The best practice recommendations relate to matters such as universality, funding, efficient administration, effective codes, the provision of advice and information, efficient complaint handling, adjudication, sanctions, compliance and monitoring as well as awareness. ${ }^{77}$ To an extent, the best practice model assists in achieving more consistency amongst the various self-regulatory organisations in Europe. ${ }^{78}$

Verbruggen "Enforcement of Transnational Private Regulation" 306.

Cunningham 2000 JPM 63.

EASA 2003 http://bit.ly/1ZRISKV 17.

Verbruggen 2013 Regulation \& Governance 516.

Cunningham 2000 JPM 65-66; EASA 2003 http://bit.ly/1ZRISKV 18.

Verbruggen "Enforcement of Transnational Private Regulation" 310.

Gray 2005 Young Consumers 22; Verbruggen 2013 Regulation \& Governance 516.

The overview is published in the form of the EASA Blue Book (EASA 2013 http://bit.ly/1TbKhw7; De Stadler Consumer Law Unlocked 60).

Scott 2012 German Law Journal 1335.

Verbruggen Transnational Private Regulation xiii.

EASA $2004 \mathrm{http}: / /$ bit.ly/1TTSqCr.

Verbruggen "Enforcement of Transnational Private Regulation" 305. 


\subsection{United Kingdom}

\subsubsection{Code of Non-Broadcast Advertising, Sales Promotion and Direct Marketing}

There is comprehensive self-regulation of prize promotions in the United Kingdom and the relevant industry codes can therefore serve as useful examples for comparative purposes. ${ }^{79}$ The United Kingdom Code of NonBroadcast Advertising, Sales Promotion and Direct Marketing (the CAP Code) is compiled by the Committee of Advertising Practice (CAP) and enforced by the United Kingdom's Advertising Standards Authority. ${ }^{80}$ The CAP Code contains a section dedicated to sales promotions..$^{81}$ There are also non-binding guidelines in respect of prize promotions. ${ }^{82}$

The CAP Code enjoins promoters to display equitable, prompt, efficient, fair and honourable conduct, and to avoid causing consumer disappointment, when conducting sales promotions. ${ }^{83}$ In addition, its provisions are aimed at protecting consumers and their safety, and require that promotions must be suitable and not cause offence. ${ }^{84}$

In defining a sales promotion, the CAP Code states that it "can provide an incentive for the consumer to buy by using a range of added direct or indirect benefits, usually on a temporary basis, to make the product more attractive". ${ }^{85}$ It mentions "text-to-wins, instant-wins, competitions and prize draws" as examples of sales promotions. ${ }^{86}$

While promoters often state that promotional goods are "subject to availability", the CAP Code requires that promoters must ensure that they anticipate reasonable demand ${ }^{87}$ In general, promoters are required to ensure that they organise and administer their competitions properly in

79 In Great Britain, prize promotions are regulated on a statutory level by the Gambling Act 2005, and in particular by the provisions s 339 in conjunction with Schedules 1 and 2. (The Gambling Act uses the term "prize competition" instead of "prize promotion".) For a discussion of the relevant statutory provisions, see Circus Promotional Marketing Law 38-48; Crown, Bray and Earle Advertising Law 233-242; Dresden "United Kingdom" 275-277.

80 CAP 2014 http://bit.ly/1YsfvNZ. See Circus Promotional Marketing Law 52-53; Dresden "United Kingdom" 278-279; Crown, Bray and Earle Advertising Law 242243.

81 Section 8 of the CAP Code.

82 CAP $2013 \mathrm{http}: / /$ bit.ly/1TdC6Ko.

83 Rule 8.1 of the CAP Code.

84 See rules 8.1 to 8.7 of the CAP Code.

85 Section 8: "Definition" of the CAP Code.

86 Section 8: "Definition" of the CAP Code.

87 Rules 8.9-8.13 of the CAP Code. 
order to avoid consumer complaints. ${ }^{88}$ Prizes must also be awarded within the advertised time period - "normally within thirty days". 89

The CAP Code contains detailed provisions relating to the disclosure of information, and promoters are required to communicate all key terms and conditions to consumers, particularly in circumstances where consumers might be misled if they are not aware of those terms and conditions. ${ }^{90}$ The terms and conditions must not be too complicated, and promoters should only in exceptional circumstances amend or supplement them. ${ }^{91}$ If space and time does not permit disclosure of the full terms and conditions, promoters must direct consumers to another source where the terms and conditions can be found. ${ }^{92}$ In the context of prize promotions, promoters must explain to consumers how they can participate, ${ }^{93}$ describe any available alternative entry route ${ }^{94}$ and indicate the competition's start date $^{95}$ and closing date. ${ }^{96}$ Promoters must mention any proof of purchase requirements, ${ }^{97}$ entry restrictions (such as age restrictions or consent requirements), ${ }^{98}$ and limits on the number of entries that will be accepted. ${ }^{99}$ The terms and conditions must disclose the date by which prizes will be handed over if this will happen more than thirty days after the competition has closed. ${ }^{100}$ They must also disclose how and when winning entrants will be notified that they have won, and winners' names must be published or made available on request. ${ }^{101}$ The terms and conditions must contain details of how winners will be used for publicity purposes after the competition (if applicable). ${ }^{102}$ The promoters name and correspondence address must be communicated as well. ${ }^{103}$

Rule 8.14-8.15 of the CAP Code.

Rule 8.15.1 of the CAP Code.

Rule 8.17 of the CAP Code.

Rule 8.23 of the CAP Code. Promoters must inform participants where they can obtain the supplemental or changed rules, and such rules must not contain anything that would have caused someone to refrain from participating.

Rule 8.16 and 8.28 of the CAP Code.

Rule 8.17.1 of the CAP Code. The promoter must, inter alia, disclose significant participation conditions and costs.

Rule 8.17.2 of the CAP Code.

Rule 8.17.3 of the CAP Code.

Rule 8.17.4 of the CAP Code. Promoters must also avoid changing closing dates, unless due to circumstances beyond their control (Rule 8.17.4.e).

Rule 8.17.5 of the CAP Code.

Rule 8.17 .7 of the CAP Code.

Rule 8.28.1 of the CAP Code.

Rule 8.28.3 of the CAP Code.

Rule 8.28.5 of the CAP Code. Promoters must observe winners' privacy and comply with relevant legal restrictions in this regard.

Rule 8.28.9 of the CAP Code.

Rule 8.17.9 of the CAP Code. 
Prizes are central to competitions and the CAP Code contains detailed provisions in this regard. It requires promoters to disclose the number and nature of prizes. ${ }^{104}$ They may not create the impression that prizes can be won if that is not the case. ${ }^{105}$ They must also not "exaggerate consumers' chances of winning", ${ }^{106}$ or create the false impression that the consumer has won a prize or stands a chance to do so if the consumer must incur a cost to do so or if there is no prize to be won. ${ }^{107}$ The promotion's rules must state whether the promoter will be entitled to substitute prizes with cash alternatives. ${ }^{108} \mathrm{~A}$ promoter should withhold prizes only if entrants have not complied with the entry requirements, ${ }^{109}$ but can do so if consumers were informed in advance that prizes might not be awarded if there were insufficient entries. ${ }^{110}$ If the winners are determined by way of a prize draw, the process must be absolutely random and an independent person must oversee the draw (unless the results are determined by a computer). ${ }^{111}$ In instant-win competitions the prizes must be available immediately or winners must be able to receive their prizes without delay. ${ }^{112}$

\subsubsection{The PhonepayPlus Code of Practice (PCP)}

If a promoter will use premium rated telephone services as part of a competition, it must observe the relevant provisions of the PCP. ${ }^{113}$ The latter regulates the provision of premium rate telephone services in general. ${ }^{114}$ It requires that service providers must make sure that consumers are provided with sufficient information, particularly relating to

104 Rule 8.17.6 of the CAP Code. If the exact number of prizes is not known, the promoter must disclose a reasonable estimate. Prize descriptions must be clear and the associated costs must be disclosed clearly (CAP 2013 http://bit.ly/1TdC6Ko 4).

105 Rule 8.19 of the CAP Code. The rule also requires promoters to distinguish between gifts (that are usually awarded to most consumers) and prizes (that are normally awarded to only a few participants). Promoters must also avoid using the term "awards" in a vague manner (CAP 2013 http://bit.ly/1TdC6Ko 3).

106 Rule 8.20 of the CAP Code. Promoters may also not "claim or imply that consumers are luckier than they are" (Rule 8.21).

107 Rule 8.21.1 of the CAP Code.

108 Rule 8.28.2 of the CAP Code.

109 Rule 8.27 of the CAP Code.

110 CAP 2013 http://bit.ly/1TdC6Ko 5.

111 Rule 8.24 of the CAP Code.

112 Rule 8.25 of the CAP Code. In addition, if a promoter has run an instant-win promotion, it must obtain an independently audited statement regarding the distribution of the prizes.

113 PhonepayPlus 2015 http://bit.ly/1snqDBG (PCP).

114 The PCP has been accredited under s 121 of the Communications Act 2003, and is binding in respect of controlled premium rate services, while compliance is voluntary in respect of other premium rate services. See para 1.2 of the PCP. 
the costs of premium rate services. ${ }^{115}$ Consumers must be treated fairly. ${ }^{116}$ Harm must be avoided. ${ }^{117}$

PhonepayPlus has also issued a guidance note in respect of prize promotions. ${ }^{118}$ It requires that promoters must compile comprehensive competition terms and conditions. ${ }^{119}$ Consumers must not be misled, ${ }^{120}$ and additional information should be made available to consumers upon request. ${ }^{121}$ Prize promotions should be conducted in a fair and equitable manner. ${ }^{122}$ Promoters must also consider the implications of the Gambling Act 2005 and know when a competition will be classified as a lottery. ${ }^{123}$

\section{Self-regulation of advertising in South Africa}

Advertising regulation in South Africa consists of a combination of selfregulation, common law and legislation. ${ }^{124}$ The self-regulation component consists mainly of the Code of Advertising Practice (ASA Code), which is enforced by the Advertising Standards Authority of South Africa (ASASA), and the Code of Conduct of the Wireless Application Service Providers' Association (the WASPA Code). Promotional competitions often fall within the field of advertising in South Africa. ${ }^{125}$ One needs to examine the relevant self-regulatory industry codes in order to identity and consider the provisions that deal with promotional competitions in particular.

\footnotetext{
115 See para 2.2 of the PCP.

116 Paragraph 2.3 of the PCP.

117 Paragraphs 2.4-2.5 of the PCP.

118 PhonepayPlus date unknown http://bit.ly/1V3Nayx.

119 PhonepayPlus date unknown http://bit.ly/1V3Nayx para 1.

120 PhonepayPlus date unknown http://bit.ly/1V3Nayx para 2.

121 PhonepayPlus date unknown http://bit.ly/1 V3Nayx para 3.

122 PhonepayPlus date unknown http://bit.ly/1 V3Nayx para 4.

123 PhonepayPlus date unknown http://bit.ly/1V3Nayx para 5.

124 Vos Regulating Offensive Advertising 30. The common law recognises, inter alia, personality rights, which include the right to identity and privacy (Woker Advertising Law 20-34; De Jager and Smith Advertising and the Law 53-54). In an advertising context, this means that an advertiser may not use someone's image or photograph in an advertisement without authorisation. See, for example, O'Keefe $v$ Argus Printing and Publishing Co Ltd 19543 SA 244 (C); Kumalo v Cycle Lab (Pty) Ltd (31871/2008) [2011] ZAGPJHC 56 (17 June 2011); Wells v Atoll Media (Pty) Ltd 20104 All SA 548 (WCC). The common law also relates to contractual aspects of advertising and matters such as puffery (Woker Advertising Law 49-67). The sources of the statutory regulation of advertising can be found in the CPA, for example s 29, while the Constitution of the Republic of South Africa, 1996 also regulates matters such as privacy (s 14) and the freedom of expression (s 16).

125 The term "advertising" is used in its broad sense here. Technically, promotional competitions fall within the scope of sale promotion. (See fn 1 above.)
} 


\subsection{Advertising Standards Authority of South Africa}

The ASASA was established by role-players in the advertising and marketing industries in order to self-regulate advertising in South Africa and to promote integrity in advertising. ${ }^{126}$ The ASA Code is the cornerstone of the ASASA's regulatory functions. ${ }^{127}$ It is founded on the principle that advertising "should be legal, decent, honest and truthful". ${ }^{128}$ The ASASA is a voluntary association. The ASA Code therefore does not have the effect of generally binding legislation. (This may change if the ASA Code is prescribed and accredited as an industry code in terms of section 82 of the CPA.) ${ }^{129}$ However, all members of the ASASA are bound by the ASA Code. ${ }^{130}$ In addition, the Electronic Communications Act ${ }^{131}$ requires that all broadcasting licensees must adhere to the ASA Code's provisions. ${ }^{132}$ The ASA Code applies to "the advertiser, the advertising practitioner and the medium involved in the publication of the advertiser's message to the public", to the extent that they are bound by the ASA Code. ${ }^{133}$

The ASA Code's provisions cover a broad range of matters related to advertising. It also contains some limited provisions relating to competitions in particular. If an advertiser advertises a competition, the ASASA may require the advertiser to provide substantiation that the competition is legal. ${ }^{134}$ The ASA Code also contains some provisions in respect of fundraising competitions. ${ }^{135}$ Furthermore, it requires that if an advertisement displays the value of a prize, the value must be inclusive of "VAT". ${ }^{136}$ Presumably, "VAT" refers to "value-added tax" levied under the

126 ASASA 2015 http://bit.ly/24SaaDn. For more information about the ASASA and its functions see, for example, Van Heerden "Marketing" paras 29-34; Brand Media Law 115-117; Schimmel Advertising Law 1-12; De Jager and Smith Advertising and the Law 3-21; Woker Advertising Law 20-34; Vos Regulating Offensive Advertising 3144.

127 ASASA $2015 \mathrm{http}: / /$ bit.ly/1Otx6zh (ASA Code).

128 Preamble, $\mathrm{s} 1.1$ of the ASA Code.

129 See fn 32 above.

130 Preamble, $\mathrm{s} 1.1$ of the ASA Code.

131 Electronic Communications Act 35 of 2005.

132 See s 55 of the Electronic Communications Act 35 of 2005. See Van Heerden "Marketing" para 33. The position was similar under the repealed Independent Broadcasting Act 153 of 1993 (see Brand Media Law 115).

133 ASA Code, Preface, para 7.

134 ASA Code, s III 8.1.1. The substantiation must be "in the form of acceptable legal advice". It is submitted that the written opinion of an attorney or advocate will meet this requirement.

135 Fund-raising competitions fall outside the scope of this work. However, readers are referred to $\mathrm{S}$ III 8.1.3 of the ASA Code in this regard.

136 ASA Code, s III 8.1.2. 
Value-Added Tax Act. ${ }^{137}$ It is submitted that the ASA Code contains this requirement in order for consumers to be informed of the full value of the prize. However, it is not quite clear why the ASASA considered it necessary to regulate this. It is submitted that the consumer would not have been severely prejudiced if the advertised value had been exclusive of value-added tax. Of course, if the consumer were required to purchase goods to a certain value in order to enter the competition, it would have been important to display the value with value-added tax included. In any event, the Value-Added Tax Act provides that prices shall be deemed to include value-added tax, ${ }^{138}$ and a vendor is required to include the tax in the advertised prices. ${ }^{139}$

In the context of timeshare advertising, the ASA Code states that an advertiser may not refer to gifts or awards as "prizes" except if a competition is being run. ${ }^{140}$ Furthermore, the ASASA's Food and Beverage Code provides that a competition may not be targeted at minor children unless the advertising for the competition states that parents or legal guardians must accept the competition offer on behalf of their children. ${ }^{141}$ In relation to alcohol advertising, Appendix A to the ASA Code states that competitions aimed at children "may not be linked to any alcohol beverage brand or product through sponsorship", and advertising should make it clear that persons younger than eighteen years may not participate in competitions that promote alcohol brands or products. ${ }^{142}$

Competition organisers often expect winners to participate in promotional activities and require the use of their images and photographs in promotional and advertising material. In this regard the ASA Code states that advertisers may not depict living persons in advertisements without the prior consent of such persons. ${ }^{143}$ Accordingly, organisers would have to obtain prior permission from competition winners and participants before using their photographs in any advertising material. However, there are exceptions to this rule. The organiser would not need to obtain consent if the persons are depicted in background shots, provided that the usage is not "defamatory, offensive or humiliating" and the advertisement must be withdrawn if it receives an objection from a person depicted in the

\footnotetext{
137 Value-Added Tax Act 89 of 1991.

138 Section 64(1) of the Value-Added Tax Act 89 of 1991.

139 Section 65. of the Value-Added Tax Act 89 of 1991.

140 ASA Code, Appendix F 8.3.

141 ASA Code, Appendix J 13.4.

142 ASA Code, Appendix A (Alcohol Advertising - ARA), "Additional Rules Relating to Promotions", para 1.

143 ASA Code, s II 11.1.
} 
advertisement. ${ }^{144}$ Consent would also not be required if, in the ASASA's opinion, the depiction "is not inconsistent with the subject's right to a reasonable degree of privacy and does not constitute an unjustifiable commercial exploitation of the individual's fame or reputation". ${ }^{145}$

The ASASA does not carry out advertising monitoring and will not of its own accord initiate steps against infringers of the ASA Code. ${ }^{146}$ If the promoter of a competition does not comply with the ASA Code's provisions, a consumer or competitor can file a complaint with the ASASA. ${ }^{147}$ It must be kept in mind that the ASA Code regulates advertising only. Therefore, in the context of promotional competitions, a complaint would typically relate to the content of a competition's advertising and marketing materials. ${ }^{148}$ Complaints would not necessarily relate to the actual mechanics of a competition, although the adviser can be required to provide proof that the competition is lawful. ${ }^{149}$

If a complaint is filed, the alleged infringer will have an opportunity to respond before the complaint will be considered by the ASASA's Directorate, Advertising Standards Committee or Advertising Industry Tribunal. ${ }^{150}$ If the complaint is upheld, the infringer may be ordered to withdraw the relevant advertising, ${ }^{151}$ to submit an amended version for pre-clearance, ${ }^{152}$ or to submit all further advertising for pre-clearance for a limited period. ${ }^{153}$ A ruling can involve adverse publicity for the offender too, such as the publication of its name. ${ }^{154}$ The ASASA can also require the offender to publish the ruling against it. ${ }^{155}$ However, the ASASA is not empowered to impose fines or require advertisers to comply with their own advertising. ${ }^{156}$

The ASA Code is binding on members of the ASASA only. However, these members include a wide variety of industry organisations and trade

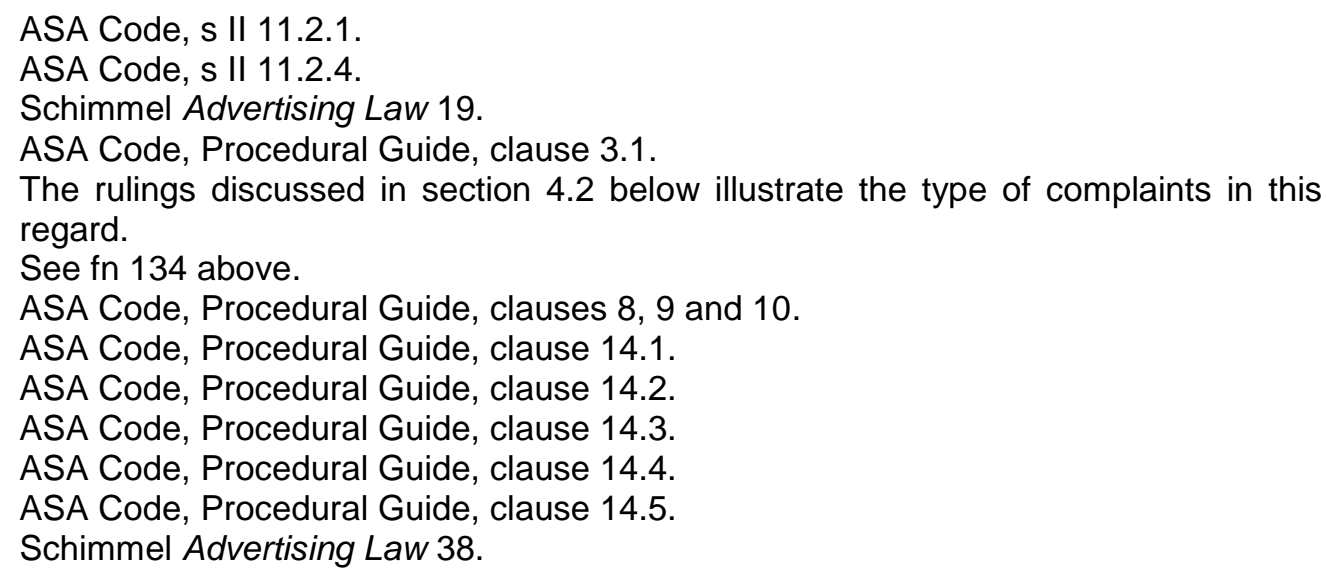


associations. ${ }^{157}$ Accordingly, although an individual advertiser might not be an ASASA member, the ASA Code will still apply if the relevant advertising is carried by an entity such as a broadcaster or newspaper that belongs to an association which is an ASASA member. If the ASASA rules against an advertiser and it fails to comply with the ruling, the ASASA can issue a socalled ad alert. ${ }^{158}$ If this is done, no ASASA member will carry or publish the offending advertiser's advertising. ${ }^{159}$ If the ASA Code is eventually accredited by the National Consumer Commission in terms of the CPA's provisions, a breach of the ASA Code will also constitute prohibited conduct and a fine could be imposed by the National Consumer Tribunal. ${ }^{160}$

\subsection{Examples of ASASA rulings relating to promotional competitions}

On a regular basis the ASASA publishes rulings relating to complaints considered by the ASASA's dispute resolution bodies. ${ }^{161}$ From time to time those complaints relate to advertising involving competitions. Often the complaints have to do with misleading, dishonest or ambiguous claims in such advertising. For example, in a complaint against a competition conducted by a newspaper, the ASASA Directorate decided that the relevant advertising material was misleading and contravened Section II 4.2.1 of the ASA Code, because the material created the impression that a participant would win a motor vehicle if the participant held a specific number, while the participant would in fact receive only the opportunity to win. ${ }^{162}$ In another matter involving misleading advertising, the advertiser undertook to change its advertising material because the material stated that participants would receive one competition entry for every fax received using the advertiser's service, while the terms and conditions

See para 3 of the ASA Code's Preface.

ASA Code, Procedural Code, clause 15.4.

Schimmel Advertising Law 40.

De Stader Consumer Law Unlocked 58 fn 10. See also fn 32 above.

Rulings are published on the ASASA's website located at www.asasa.org.za.

Sowetan BMW Competition / S Zwane / 2014 - 1841 F (8 January 2015). The original advertising material stated: "If you have the lucky number 114, you will receive the BMW1 and be proclaimed the Grand Prize Winner". The material was then amended as follows: "It is you who can become the owner of the brand new BMW1! Check right now: If you have lucky number 114 , follow the steps to claim your BMW1". The Directorate held that the original and amended material was misleading, because people who received the lucky number would only become eligible to win the prize, and would not in fact win the prize. 
stated that at least twenty faxes would have to be received in order for someone to stand a chance to win a prize. ${ }^{163}$

Advertisers should also take care to avoid misleading claims in relation to the prizes offered in competitions. For example, in Denny Mushrooms SMS Competition / $E$ A Van Zy/164 the advertiser's product packaging displayed this statement: "WIN R250 000 WORTH OF GROCERY VOUCHERS". The ASASA Directorate ruled that the statement was ambiguous and misleading, because it could be interpreted in various ways (for example, one winner could win vouchers to the full value or several winners could win vouchers up to the total value). ${ }^{165}$ In Denny Mushrooms, the Directorate referred to the ruling in Sta-Soft / T Marshall'166 in which the advertising material stated: "Win one of 10 makeovers worth R100 000!" In that matter, the Directorate had found that the statement was misleading because it was not clear whether all ten makeovers would be worth R100 000 in aggregate (in other words, R10 000 per makeover), or whether each makeover was worth R100 000. ${ }^{167}$ Generally, advertisers must be able to substantiate advertised prize values. ${ }^{168}$ Prize descriptions must also not be misleading. ${ }^{169}$

163 Olympics 2012 Competition / N van der Lingen / 19461 (15 February 2012). For other examples of possibly misleading advertising in relation to competitions, see MTN Man United Competition / R Haupt / 17738 (27 June 2011) (where the advertising material failed to disclose that entrants had to be MTN subscribers); Federal Mogul Competition / M Kent / 13839 (28 July 2009) (where a television commercial advertised a competition, but the complainant received a text message which implied that the competition had already closed); Ster Kinekor Competition / M du Plessis / 8610 (13 April 2007) (which involved a claim that the value of the prize was inflated); SMS Competitions / C Pearce / 8539 (13 March 2007) (a complaint regarding advertising which was unclear regarding the costs that would be incurred by entrants); DSTV Competition / JW Sherwood / 4578 (14 March 2006) (where the complainant averred that the advertising material failed to disclose that a premium would be charged in respect of text message entries). In all of those matters, the advertisers agreed to withdraw or amend the relevant advertising and the Directorate therefore did not consider the merits of the complaints.

164 Denny Mushrooms SMS Competition / E A Van Zyl / 7383 (24 November 2006) (hereafter Denny Mushrooms).

165 The Directorate referred to the competition's terms and conditions, and found that the advertiser would not be allowed to rectify the confusion by way of the terms and conditions.

166 Sta-Soft / T Marshall / 1683 (23 November 2004).

167 Also see Racumin / M M Keys / 1834 (7 February 2005), where the Directorate held that an advertisement for a competition was misleading. The advertisement contained the following statement: "SMS \& WIN! 10 Piece Braai Set $\cdot$ Cheese \& Wine Picnic Bag - Backpack Picnic Set". The Directorate ruled that the statement was open to various interpretations. For example, it was not clear whether the winner would win one or more of the items in the advertisement.

168 See, for example, Twinsaver Spoil-Yourself Competition / Kimberly Clark / 4622 (13 June 2002), where prizes worth R91 million were advertised. (This value might seem 
The ASASA Directorate has also ruled that advertising would be misleading if it involves a competition and the advertising material (and product packaging in particular) does not display the competition's closing date. ${ }^{170}$ It is submitted that the closing date of a promotional competition should be made known in order to avoid situations where a consumer purchases a product in order to enter a competition which is being conducted in relation to that product, only to discover that the competition has already ended.

Based on previous ASASA rulings, it appears that it would be prudent for an advertiser to ensure that product packaging contains sufficient and

very high, but this is the amount that was mentioned in the ruling.) Perhaps because of the high value, the complainant was of the view that the aforesaid claim had to be substantiated. However, the Directorate dismissed the complaint when the advertiser provided supporting documentation and a report from an auditing firm in order to substantiate the claim. Also see Sunday Times Food and Travel Magazine / Mr E Schwentzek / 1044 (12 July 2004), in which a complaint was partially upheld because the advertiser did not provide substantiation for the advertised prize values, as well as DSTV Golf / Maureen Tiearney (6 November 2003), where the Directorate upheld a complaint on the basis that the value of the relevant prize was overstated.

169 Often, competition rules would state that prizes may differ from the description in the relevant advertising material. In CAT Watches / Rajash Seejarim / 1391 (13 July 2004), a winner complained that the watch that he had won did not correspond with the watches depicted in the relevant television commercial. However, the Directorate dismissed the claim on the basis that the advertisement merely described the prizes as exclusive watches and the commercial only very briefly depicted some watches without creating the impression that those watches would constitute the prizes.

170 The ASA Directorate has determined that a competition closing date is a material condition, and has ruled against advertisers who failed to display the closing date on the advertising in issue. See, for example, Brooks Sweeto / GH Smith / 725 (4 August 2005), where a competition was advertised on the label of a cool drink bottle, but the closing date was obscured because it was printed on the back of the label. In Archers / L Nel / 4779 (10 May 2006), the product label displayed no closing date, but participants were referred to the advertiser's website. The advertiser stated that it did this on purpose so that it could extend or reduce the length of the competition period. The Directorate found that this was misleading, and that the confusion caused by the product label could not be cured by way of further information on the website. In Steers / Mr T Spicer / 184 (15 September 2003) the Directorate ruled that in-store advertising for a competition was misleading because it referred the public to the advertiser's website without disclosing that persons could enter the competition only by way of text messages. In Coca Cola Vitamin Water / S Antonellos / 2015576F (30 April 2015), the Directorate ordered the advertiser to withdraw its packaging from the market because it referred to a competition that had ended long ago. In contrast, in Magnum Competition / P Howard / 2014 - 1261F (19 August 2014) the Directorate dismissed a complaint where the complainant purchased a product in order to enter a competition (which had in fact already closed). The ruling was based on the fact that the closing date was clearly displayed on the packaging and that consumers would therefore have been able to verify whether or not the competition was still open for entry. 
clear information regarding a competition and how it works. ${ }^{171}$ For example, if the competition involves text message entries, advertisers must ensure that the full costs of the text messages are properly disclosed. ${ }^{172}$ However, although a competition's closing date might be a material term that should be displayed on product packaging ${ }^{173}$ the ASA Code does not require the full terms and conditions of the competition to be displayed in advertising material relating to the competition. ${ }^{174}$ It is submitted, however, that it would be prudent for the advertiser to make th full terms and conditions available, since the terms and conditions might protect the advertiser in disputes with participants or winners. ${ }^{175}$ In general, in view of previous ASASA rulings, a promoter should ensure that the contents of a competition advertisement are accurate. ${ }^{176}$

\subsection{Wireless Application Service Providers' Association}

The detailed self-regulation of promotional competitions is also found in the industry code adopted by the Wireless Application Service Providers' Association (WASPA). The WASPA is a voluntary association which was established to self-regulate mobile-based value-added service providers in South Africa. ${ }^{177}$ Value-added service providers are persons or entities "that provide services and data through wireless and mobile devices over public networks". ${ }^{178}$ The WASPA "aims to ensure that consumers receive world-class services and that members operate according to ethical and

171 See, for example, City Mageu Competition / Mageu Number One / 1758 (17 November 2004), where a competitor complained about various issues with the information on the advertiser's packaging, including that it contained no closing date, gave insufficient details about the prizes, and gave no proper explanation about the way in which the competition would work. However, the Directorate did not consider the merits of the complaint, because the advertiser undertook to withdraw the competition.

172 See the concluding comments of the ASA Directorate in R1 Million House Competition / Mr B Oldenboom / 1402 (30 July 2004).

173 See the rulings in fn 170 above.

174 See the ASASA Directorate's comments on the second preliminary point raised by the complainant in Supa Quick / Tiger Wheel \& Tyre / 10316 (13 December 2007).

175 See, for example, Sunday Times Food and Travel Magazine / Mr E Schwentzek / 1044 (12 July 2004), where a winner complained that he was forced to make use of the prize within a certain period. The ASA Directorate dismissed this complaint on the basis that the relevant advertisement contained a clear condition in this regard and the winner was deemed to have accepted the condition by entering the competition.

176 The accuracy of an advertisement was the focus in Sokka Kings / I Butler / 706 (3 June 2005). In that matter, a television commercial relating to a competition referred to "Tshwane". The complainant argued that the advertisement was misleading, because it made mention of "Tshwane", while the city's name was still "Pretoria". The advertiser undertook not to broadcast the commercial again.

177 WASPA 2015 http://bit.ly/1TTTplZ.

178 WASPA 2016 http://bit.ly/24SdG0p s 2. 
reasonable business practices". ${ }^{179}$ In order to achieve this, the WASPA enforces the WASPA Code, ${ }^{180}$ which is binding on all WASPA members. ${ }^{181}$ The WASPA's media monitors conduct daily research in order to verify whether or not WASPA members are complying with the WASPA Code. ${ }^{182}$ The WASPA is also a member of the International Audiotex Regulators Network (IARN). ${ }^{183}$ The IARN is an international organisation that was formed for the purposes of sharing information regarding the regulation of phone-paid services. ${ }^{184}$

The WASPA Code contains a section which regulates promotional competitions specifically. ${ }^{185}$ It defines a "promotional competition" as "any competition, game, scheme, arrangement, system, plan or device for distributing prizes as defined in section 36 of the Consumer Protection Act, 2008 ". ${ }^{186}$ In view of the cross-reference to the CPA, it appears that section 18 of the WASPA Code is focussed on chance-based competitions.

Under the WASPA Code, the maximum permitted cost of a competition entry is R1.50. ${ }^{187}$ This is the same as the limit specified in the Consumer Protection Act Regulations. ${ }^{188}$ The WASPA Code states that "[a]ll valid and correct entries must have the same chance of winning". ${ }^{189}$ It is submitted that promoters may therefore not discriminate between competition entries and that promoters should give all entrants the same opportunity to win. Furthermore, a competition must have a closing date (unless it is an instant win competition), and prizes must be allocated within 28 days of that date. ${ }^{190}$ For a period of 30 days after the closing date, the promoter must send a reply to further entrants, advising them that the competition has closed. ${ }^{191}$ (It is assumed that the references to

WASPA 2016 http://bit.ly/1TdFqoN (WASPA Code) para 1.2. WASPA $2016 \mathrm{http}: / /$ bit.ly/1TdFqoN (WASPA Code).

WASPA Code para 1.5. Previously, WASPA enforced both the WASPA Code as well as the so-called "Ad Rules", which were very detailed. However, the WASPA recently consolidated the WASPA Code and the Ad Rules into one document (Jacobson $2014 \mathrm{http}: / /$ bit.ly/1TNObFG).

WASPA $2015 \mathrm{http}: / /$ bit.ly/1TTTplZ.

WASPA $2015 \mathrm{http}: / / \mathrm{bit} . l y / 1 T T T p l Z$.

IARN 2009 http://www.iarn.org/. The IARN has also issued a handbook that contains guidelines regarding the regulation of phone-paid services. The handbook is available on the IARN's website.

Section 18 of the WASPA Code.

Section 18.1 of the WASPA Code.

Section 18.2 of the WASPA Code. This limit is the same as the one in reg 11(1) of the Consumer Protection Act Regulations (GN R293 in GG 34180 of 1 April 2011).

See Consumer Protection Act Regulations, reg 11(1).

Section 18.3 of the WASPA Code.

Sections 18.6 and 18.7 of the WASPA Code.

Section 18.8 of the WASPA Code. 
"days" imply calendar days. The WASPA Code refers to "days" in section 18, while it refers to "business days" in some other sections.) A promoter may also not extend a competition period or fail to award prizes on the basis that insufficient entries were received or that the entries were of inadequate quality. ${ }^{192}$

An offer which invites the public to enter a promotional competition must at least contain the information prescribed by the WASPA Code. Section 18.4 requires that the offer must state the following:

(a) the competition to which the offer relates;

(b) the steps required by a person to participate in the competition;

(c) the full cost to enter the competition;

(d) the basis on which the results of the competition will be determined;

(e) the closing date for the competition;

(f) how the results of the competition will be made known;

(g) how a person can obtain a copy of the competition rules; and

(h) how the successful participant can obtain the prize.

These requirements are very similar to those contained in section 36(5) of the CPA. In previous versions, the WASPA Code required that the advertising material had to include, inter alia, "any information which is likely to affect a decision to participate". ${ }^{193}$ It is submitted that it would have been difficult to comply with such a requirement, since various factors might influence a participant when a potential participant considers whether or not to enter a competition. This could include, for example, the odds of winning or the number of expected participants.

The information listed in section 18.4 of the WASPA Code must be contained in an advertisement relating to the competition, or must be provided to entrants before they enter. ${ }^{194}$ The WASPA Code also prohibits certain practices in relation to promotional competitions. ${ }^{195}$ In addition,

\footnotetext{
192 Section 18.6 of the WASPA Code.

193 De Stadler Consumer Law Unlocked 69.

194 Section 18 of the WASPA Code. As an example, the subsection states that a promoter may redirect an entrant to a website that contains the terms and conditions.

195 Section 18.9 of the WASPA Code states that a promotional competition must not:
} 
promotional competitions that are aimed at children may not involve cash prizes or lengthy or complicated rules. ${ }^{196}$

The WASPA adjudicates complaints relating to breaches of the WASPA Code on a regular basis. ${ }^{197}$ Many complaints pertain to competitions. In some instances, the matters related to situations where competitions' terms and conditions or entry costs were not properly displayed in the relevant marketing material, ${ }^{198}$ or where recipients of text messages relating to a competition were not able to opt out from receiving further messages. ${ }^{199}$ In other cases the complaints involved matters where competitions were linked to subscription services. ${ }^{200}$ Illegal competitions have been the subject of complaints as well. ${ }^{201}$ There are also examples of other breaches of the WASPA Code in the context of competitions. ${ }^{202}$

As opposed to the ASASA, the WASPA actively monitors the advertising and services of WASPA members in order to determine if they comply with the provisions of the WASPA Code. ${ }^{203}$ Anyone, including a member of the public, a competitor or the WASPA media monitor, may file a complaint with the WASPA in relation to a WASPA member's breach of the WASPA Code. ${ }^{204}$ Complaints are adjudicated by independent adjudicators appointed by the WASPA. ${ }^{205}$

If a WASPA member is found to have contravened the WASPA Code, it could be ordered to remedy the breach or pay a fine. ${ }^{206}$ Its WASPA

(a) use words such as "win" or "prize" to describe items intended to be offered to all or a substantial majority of the participants;

(b) exaggerate the chance of winning a prize;

(c) suggest that winning a prize is a certainty; or

(d) suggest that the party has already won a prize and that by contacting the promoter of the competition the entrant will have definitely secured that prize.

196 Section 23.3 of the WASPA Code.

197 WASPA adjudication reports are available on the WASPA's website. Note that many of the complaints were adjudicated under previous versions of the WASPA Code.

198 For example, Clickatell (Complaint No 8128); HP Computek (Compliant No 11370); Clickatell (Complaint No 8228); Exactmobile (Compliant No 4196).

199 For example, Mira Networks (Complaint No 4696).

200 See, for example, Mobile NOBO (IP) / Tanla Mobile (SP) (0118) (Compliant No 15268).

201 For example, Celerity Systems (BulkSMS) (Complaint No 7180); Independent SMS Telecommunications (Pty) Ltd (Complaint No 0067).

202 For example, Viamedia (SP) Xcite Mobile (IP) (Compliant No 12969), where s 9.1.6 of the then current version of the WASPA Code was breached because the word "win" was used in a situation where prizes were available to most or all participants (pages 4-5 of the report).

203 WASPA Code, ss 24.3 and 24.82.

204 WASPA Code, s 24.5.

205 WASPA Code, s 24.1.

206 WASPA Code, ss 24.43(a) and (c). 
membership could be suspended or terminated as well. ${ }^{207}$ Since WASPA member usually provide wireless application services to other businesses (for example, in order to send direct marketing messages), members can be required to disclose the identity of their customers, to cease providing services to them or to withhold any moneys due to them. ${ }^{208}$ The network operator over whose network the member's services are provided could also be advised to take steps such as terminating or suspending the member's access to a specific number or category of services, withholding funds due to the member, paying such funds to the WASPA as a fine, or issuing a refund to customers. ${ }^{209}$ The WASPA Code extends beyond WASPA members as well, since notices can be issued to non-members too. ${ }^{210}$ If a WASPA member allows a non-member to breach the WASPA Code's provisions, such a member will be deemed to be in breach of the same provisions. ${ }^{211}$ It appears, therefore, that the WASPA Code makes provision for extensive sanctions that could be very effective in practice. Further, in contrast with the ASA Code, the WASPA Code's provisions and sanctions extend beyond mere advertising and address the actual services provided by WASPA members too.

\subsection{General}

Apart from the provisions of the ASA Code and the WASPA Code, promoters need to ensure that they comply with the requirements of any other applicable industry codes. For example, in the context of direct marketing, members of the Direct Marketing Association of Southern Africa must comply with its Code of Ethics and Standards of Practice. ${ }^{212}$ In the pharmaceutical industry, organisations who are members of the Marketing Code Authority must heed the requirements of the Authority's Code of Marketing Practice. ${ }^{213}$

\footnotetext{
207 WASPA Code, ss 24.43(d) and (e).

208 WASPA Code, ss 24.43(f) to (h).

209 WASPA Code, s 24.44.

210 WASPA Code, ss 24.50 to 24.53.

211 WASPA Code, s 24.53.

212 The Code of Ethics and Standards of Practice of the Direct Marketing Association of Southern Africa is attached to the ASA Code as Appendix C. Clause 10.2.1 of the version attached to the ASA Code warns association members that lotteries and contests are "highly regulated by law" and that they should seek professional advice in order to conduct contests and the like.

213 MCA $2015 \mathrm{http}: / /$ bit.ly/23QNKjB. The Code regulates competitions aimed at healthcare professionals and healthcare providers (clause 19.4) as well as competitions that are open to consumers (clause 37.2). It prohibits competitions that require entrants to purchase health products in order to enter, and promoters may not award health products as prizes (clause 37.2).
} 


\section{Conclusion}

There appears to be a high level of self-regulation in the marketing and advertising industry in South Africa. This should provide some protection to consumers and offer recourse in situations where promoters follow abusive advertising and marketing practices in general. However, it seems that the provisions relating to promotional competitions are quite limited, particularly when compared to the comprehensive provisions contained in the United Kingdom's CAP Code. In essence, the ASA Code expects promoters merely to ensure that their competitions comply with applicable law and that prize values are displayed as VAT inclusive amounts. ${ }^{214}$ Although the provisions relating to promotional competitions are limited, it does appear that the ASASA rules on complaints that relate to promotional competitions from time to time. In the relevant matters, the ASA mostly applied the provisions that relate to truthful advertising. Even so, the rulings can serve as useful guidance for promoters.

Self-regulation has the potential to be effective, flexible and continuously developing. ${ }^{215}$ When it comes to promotional competitions, this potential was left untapped in the drafting of the ASA Code. Accordingly, it is submitted that the ASASA should consider crafting provisions that can complement and amplify those contained in the CPA.

A different situation is encountered when one considers the WASPA Code. It contains more substantial provisions relating to promotional competitions and regulates matters that are not found in the CPA. For example, it requires that competitions must have closing dates and states that closing dates may not be changed. ${ }^{216}$ The WASPA Code also requires that prizes must be awarded after the closing date and promoters must do so within a specific period. ${ }^{217}$ Some of the WASPA Code's provisions are also simpler and clearer than those contained in the CPA. For example, the CPA prescribes the information that must be disclosed by a promoter as part of an offer to participate in a promotional competition, ${ }^{218}$ but the provisions relating to the manner in which such information must be disclosed are not entirely clear. ${ }^{219}$ The WASPA Code contains similar provisions, but they have been drafted in a simpler and

\footnotetext{
See ASA Code, ss III 8.1.1 and 8.1.2.

See $p 5$ above.

Section 18.6 of the WASPA Code.

Sections 18.6 and 18.7 of the WASPA Code.

See s 36(5) of the CPA.

See s 36(6) of the CPA.
} 
clearer manner. ${ }^{220}$ The WASPA Code regulates the marketing of promotional competitions as well. In essence, the provisions prohibit promoters from giving consumers false impressions regarding their chances of winning. ${ }^{221}$ These provisions complement and amplify the similar ones found in the CPA. ${ }^{222}$

In conclusion, it is submitted that the efficacy of industry regulation depends on industry members' cooperation with self-regulatory bodies. The relevant industry codes contain quite extensive sanctions. Complaints should be resolved efficiently and the sanctions should be used against transgressors in order to deter promoters from breaching the relevant industry codes.

\section{Bibliography}

\section{Literature}

Baldwin, Cave and Lodge Understanding Regulation

Baldwin R, Cave M and Lodge M Understanding Regulation: Theory, Strategy, and Practice (Oxford University Press Oxford 2012)

Bennett 2007 Practical Lawyer

Bennett SC "An Introduction to Sweepstakes and Contests Law" 2007 The Practical Lawyer 39-50

Black 1996 MLR

Black J "Constitutionalising Self-Regulation" 1996 MLR24-55

Black 2001 CLP

Black J "Decentring Regulation: Understanding the Role of Regulation and Self-Regulation in a 'Post-Regulatory' World" 2001 CLP 103-146

Black 2002 AJLP

Black J "Critical Reflections on Regulation" 2002 AJLP 1-35

Boddewyn Advertising Self-Regulation

Boddewyn JJ Advertising Self-Regulation and Outside Participation: A Multinational Comparison (Quorum Books New York 1988)

Boddewyn 1989 Journal of Advertising

\footnotetext{
220 See ss 18.4 and 18.5 of the WASPA Code.

221 See $\mathrm{S} 18.9$ of the WASPA Code.

222 See $s$ 36(2) of the CPA.
} 
Boddewyn JJ "Advertising Self-Regulation: True Purpose and Limits" 1989 Journal of Advertising 19-27

Brand Media Law

Brand R Media Law in South Africa (Kluwer Law International Alphen aan den Rijn 2011)

Cunningham 2000 JPM

Cunningham A "Advertising Self-Regulation in a Broader Context" 2000 JPM 61-83

Casey and Scott 2011 JLS

Casey D and Scott C "The Crystallization of Regulatory Norms" $2011 \mathrm{JLS}$ 76-95

Circus Promotional Marketing Law

Circus P Promotional Marketing Law: A Practical Guide $6^{\text {th }}$ ed (Bloomsbury Professional Haywards Heath 2011)

Crown, Bray and Earle Advertising Law

Crown G, Bray $\mathrm{O}$ and Earle R Advertising Law and Regulation $2^{\text {nd }}$ ed (Bloomsbury Professional Haywards Heath 2010)

De Jager and Smith Advertising and the Law

De Jager $\mathrm{C}$ and Smith E Advertising and the Law (Butterworths Durban 1995)

De Stadler Consumer Law Unlocked

De Stadler E Consumer Law Unlocked (Siber Ink Cape Town 2013)

Du Plessis "Introduction to Integrated Marketing Communication"

Du Plessis F "Introduction to Integrated Marketing Communication" in Du Plessis PJ et al Integrated Marketing Communication: A Contemporary Approach $3^{\text {rd }}$ ed (Van Schaik Pretoria 2010) 1-19 
Dresden "United Kingdom"

Dresden B "United Kingdom" in Promotion Marketing Association and Global Advertising Lawyers Alliance International Promotion Marketing Law Book $2^{\text {nd }}$ ed (PMA Educational Foundation New York 2010) 268-282

Ginosar "Regulation of Advertising"

Ginosar A "The Regulation of Advertising" in Levi-Faur D (ed) Handbook on the Politics of Regulation (Edward Elgar Cheltenham 2011) 254-266

Gray 2005 Young Consumers

Gray O "Responsible Advertising in Europe" 2005 Young Consumers 1923

Gunningham and Rees 1997 L\&P

Gunningham N and Rees J "Industry Self-Regulation: An Institutional Perspective" 1997 L\&P 363-414

Haufler Public Role for the Private Sector

Haufler V A Public Role for the Private Sector: Industry Self-Regulation in a Global Economy (Carnegie Endowment for International Peace Washington DC 2001)

Huyse and Parmentier 1990 JCP

Huyse $L$ and Parmentier $S$ "Decoding Codes: The Dialogue between Consumers and Suppliers through Codes of Conduct in the European Community" 1990 JCP 253-272

International Chamber of Commerce Consolidated Code

International Chamber of Commerce Consolidated Code of Advertising and Marketing Communications Practice $9^{\text {th }}$ revision (International Chamber of Commerce Paris 2011)

Koekemoer Advertising and Sales Promotion

Koekemoer L Advertising and Sales Promotion (Juta Cape Town 2014)

Labarbera 1980 JAR

Labarbera PA "Analyzing and Advancing the State of the Art of Advertising Self-Regulation" 1980 JAR 27-38

Melville and Yeates "Section 82"

Melville $\mathrm{N}$ and Yeates $\mathrm{J}$ "Section 82" in Eiselen $\mathrm{S}$ and Naudé $\mathrm{T}$ (eds) Commentary on the Consumer Protection Act (original service) (Juta Claremont 2014) 82-1 - 82-6 
Ogus 1995 OJLS

Ogus A "Rethinking Self-Regulation" 1995 OJLS 97-108

Ramsay Consumer Law and Policy

Ramsay I Consumer Law and Policy: Text and Materials on Regulating Consumer Markets $2^{\text {nd }}$ ed (Hart Oxford 2007)

Reader 1995 U Pa J Int'I Bus L

Reader TW "Is Self-Regulation the Best Option for the Advertising Industry in the European Union? An Argument for the Harmonization of Advertising Laws through the Continued Use of Directive" 1995 U Pa J Int'l Bus L 181215

Schimmel Advertising Law

Schimmel G Advertising Law: A Guide to the Code of Advertising Practice (Juta Claremont 2014)

Scott 2012 German Law Journal

Scott C "Beyond Taxonomies of Private Authority in Transnational Regulation" 2012 German Law Journal 1329-1338

Semenik et al Advertising and Promotion

Semenik RJ et al Advertising and Promotion: An Integrated Brand Approach $6^{\text {th }}$ ed (South-Western Cengage Learning Mason 2012)

Shimp Integrated Marketing Communication

Shimp TA Integrated Marketing Communication in Advertising and Promotion $8^{\text {th }}$ ed (South-Western Cengage Learning Mason 2010)

Taylor 2011 Without Prejudice

Taylor N "Promotional Competitions - Let the Promoter Beware" April 2011 Without Prejudice 17-20

Van Eeden Consumer Protection Law

Van Eeden E Consumer Protection Law in South Africa (LexisNexis Durban 2013)

Van Heerden "Marketing"

Van Heerden C "Marketing" in Eiselen S and Naudé T (eds) Commentary on the Consumer Protection Act (original service) (Juta Claremont 2014) 1 $-6$ 
Van Heerden "Section 36"

Van Heerden C "Section 36" in Eiselen S and Naudé T (eds) Commentary on the Consumer Protection Act (original service) (Juta Claremont 2014) 36-1 - 36-15

Verbruggen Transnational Private Regulation

Verbruggen $\mathrm{P}$ Transnational Private Regulation in the Advertising Industry (Hague Institute for the Internationalisation of Law The Hague 2011)

Verbruggen "Enforcement of Transnational Private Regulation" Verbruggen $\mathrm{P}$ "Enforcement of Transnational Private Regulation of Advertising Practices: Decentralization, Mechanisms and Procedural Fairness" in Cafaggi F (ed) Enforcement of Transnational Regulation: Ensuring Compliance in a Global World (Edward Elgar Cheltenham 2012) 302-327

Verbruggen 2013 Regulation \& Governance

Verbruggen $\mathrm{P}$ "Gorillas in the Closet? Public and Private Actors in the Enforcement of Transnational Private Regulation" 2013 Regulation \& Governance 512-532

Vos Regulating Offensive Advertising

Vos SW De Gustibus non est Disputandum: Regulating Offensive Advertising in a Democratic South Africa (LLD thesis University of Pretoria 2011)

Woker Advertising Law

Woker T Advertising Law in South Africa (Juta Kenwyn 1999)

Woker 2010 Obiter

Woker T "Why the Need for Consumer Protection Legislation? A Look at Some of the Reasons behind thePpromulgation of the National Credit Act and the Consumer Protection Act" 2010 Obiter 217-231

\section{Rulings and case law}

\section{Advertising Standards Authority of South Africa}

Archers / L Nel / 4779 (10 May 2006)

Brooks Sweeto / GH Smith / 725 (4 August 2005)

CAT Watches / Rajash Seejarim / 1391 (13 July 2004) 
City Mageu Competition / Mageu Number One / 1758 (17 November 2004)

Coca Cola Vitamin Water / S Antonellos / 2015-576F (30 April 2015)

Denny Mushrooms SMS Competition / E A Van Zyl / 7383 (24 November 2006)

DSTV Competition / JW Sherwood / 4578 (14 March 2006)

DSTV Golf / Maureen Tiearney (6 November 2003)

Federal Mogul Competition / M Kent / 13839 (28 July 2009)

Magnum Competition / P Howard / 2014 - 1261F (19 August 2014)

MTN Man United Competition / R Haupt / 17738 (27 June 2011)

Olympics 2012 Competition / N van der Lingen / 19461 (15 February 2012)

R1 Million House Competition / Mr B Oldenboom / 1402 (30 July 2004)

Racumin / M M Keys / 1834 (7 February 2005)

SMS Competitions / C Pearce / 8539 (13 March 2007)

Sokka Kings / I Butler / 706 (3 June 2005)

Sowetan BMW Competition / S Zwane / 2014 - 1841 F (8 January 2015)

Sta-Soft / T Marshall / 1683 (23 November 2004)

Steers / Mr T Spicer / 184 (15 September 2003)

Ster Kinekor Competition / M du Plessis / 8610 (13 April 2007)

Sunday Times Food and Travel Magazine / Mr E Schwentzek / 1044 (12 July 2004)

Supa Quick / Tiger Wheel \& Tyre / 10316 (13 December 2007)

Twinsaver Spoil-Yourself Competition / Kimberly Clark / 4622 (13 June 2002) 


\section{Wireless Application Services Providers' Association}

Celerity Systems (BulkSMS) (Complaint No 7180)

Clickatell (Complaint No 8128)

Clickatell (Complaint No 8228)

Exactmobile (Compliant No 4196)

HP Computek (Compliant No 11370)

Independent SMS Telecommunications (Pty) Ltd (Complaint No 0067)

Mira Networks (Complaint No 4696)

Mobile NOBO (IP) / Tanla Mobile (SP) (0118) (Compliant No 15268)

Viamedia (SP) Xcite Mobile (IP) (Compliant No 12969)

\section{General}

Kumalo v Cycle Lab (Pty) Ltd (31871/2008) [2011] ZAGPJHC 56 (17 June 2011)

O'Keefe v Argus Printing and Publishing Co Ltd 19543 SA 244 (C)

Wells v Atoll Media (Pty) Ltd 201] 4 All SA 548 (WCC)

\section{Legislation}

\section{South Africa}

Constitution of the Republic of South Africa, 1996

Consumer Protection Act 68 of 2008

Consumer Protection Act Regulations (GN R293 in GG 34180 of 1 April 2011)

Electronic Communications Act 35 of 2005

Lotteries Act 57 of 1997

Independent Broadcasting Act 153 of 1993

Value-Added Tax Act 89 of 1991 


\section{United Kingdom}

Communications Act 2003

Gambling Act 2005

\section{Government publications}

GN 224 in GG 36253 of 22 March 2013

GN 817 in GG 38107 of 17 October 2014

GN R271 in GG 38637 of 30 March 2015

GN 33 in GG 39631 of 29 January 2016

\section{International instruments}

Interinstitutional Agreement on Better Law-Making Concluded between the European Parliament, the Council of Europe and the European Commission, 2003/C321/01 (2003)

\section{Internet sources}

ASASA 2015 http://bit.ly/24SaaDn Advertising Standards Authority of South Africa 2015 About the ASASA http://bit.ly/24SaaDn accessed 20 June 2015

ASASA $2015 \mathrm{http}: / /$ bit.ly/1Otx6zh

Advertising Standard Authority of South Africa 2015 Advertising Code of Practice http://bit.ly/1Otx6zh accessed 20 June 2015

Bizcommunity $2013 \mathrm{http}: / /$ bit.ly/24SapOI

Bizcommunity 2013 FASA to Handle Alternative Dispute Resolutions for Franchise Sector http://bit.ly/24SapOI accessed 16 June 2015

CAP 2013 http://bit.ly/1TdC6Ko

Committee of Advertising Practice 2013 Help Note: Promotions with Prizes http://bit.ly/1TdC6Ko accessed 11 July 2015 
CAP 2014 http://bit.ly/1YsfvNZ

Committee of Advertising Practice 2014 Code of Advertising Practice http://bit.ly/1YsfvNZ accessed 20 June 2016

Danish Consumer Ombudsman 2015 http://bit.ly/1 V22ED3

Danish Consumer Ombudsman 2015 ICC Codes http://bit.ly/1V22ED3 accessed 15 August 2015

EASA date unknown http://bit.ly/1sbV9hq

European Advertising Standards Alliance date unknown What is EASA? http://bit.ly/1sbV9hq accessed 16 June 2015

EASA date unknown http://bit.ly/1TTSmT6

European Advertising Standards Alliance date unknown South Africa http://bit.ly/1TTSmT6 accessed 16 June 2015

EASA 2003 http://bit.ly/1ZRISKV

European Advertising Standards Alliance 2003 Advertising SelfRegulation: The Essentials http://bit.ly/1ZRISKV accessed 24 August 2015

EASA 2004 http://bit.ly/1TTSqCr

European Advertising Standards Alliance 2004 The EASA Best Practice Self-Regulatory Model http://bit.ly/1TTSqCr accessed 27 August 2015

EASA 2009 http://bit.ly/1XaD0w7

European Advertising Standards Alliance 2009 International Guide to Developing a Self-Regulatory Organisation http://bit.ly/1XaD0w7 accessed 27 August 2015

EASA 2013 http://bit.ly/1TbKhw7

European Advertising Standards Alliance 2013 Blue Book 6 http://bit.ly/1TbKhw7 accessed 16 June 2015

German Association of Communications Agencies date unknown http://bit.ly/1WxZesS

German Association of Communications Agencies date unknown Germany: Self-Regulatory Organisations http://bit.ly/1WxZesS accessed 15 August 2015

IARN 2009 http://www.iarn.org/

International Audiotex Regulators Network 2009 Welcome to the IARN http://www.iarn.org/ accessed 16 August 2015 
ICC 2015 http://bit.ly/1VX1idT

International Chamber of Commerce 2015 Commission on Marketing and Advertising http://bit.ly/1VX1idT accessed 16 June 2015

ICC 2015 http://bit.ly/23QNnW1

International Chamber of Commerce 2015 Marketing and Advertising http://bit.ly/23QNnW1 accessed 15 August 2015

ICC 2015 http://bit.ly/228Wdz4

International Chamber of Commerce 2015 Self-Regulation http://bit.ly/228Wdz4 accessed 15 August 2015

Jacobson 2014 http://bit.ly/1TNObFG

Jacobson P 2014 Rewritten WASPA Code Better Regulates Mobile Services in SA http://bit.ly/1TNObFG accessed 20 June 2015

MCA 2015 http://bit.ly/23QNKjB

Marketing Code Authority 2015 The Code http://bit.ly/23QNKjB accessed 1 February 2016

PhonepayPlus 2015 http://bit.ly/1snqDBG

PhonepayPlus 2015 Code of Practice http://bit.ly/1snqDBG accessed 4 May 2015

PhonepayPlus date unknown http://bit.ly/1V3Nayx

PhonepayPlus date unknown Service-Specific Guidance Note: Competitions and Other Games with Prizes http://bit.ly/1V3Nayx accessed 15 May 2016

Senden 2005 http://bit.ly/1Ore1Dh

Senden L 2005 "Soft Law, Self-Regulation and Co-Regulation in European Law: Where Do They Meet?" 2005 EJCL http://bit.ly/1Ore1Dh accessed 12 July 2015

Swedish Advertising Ombudsman About http://bit.ly/1snrgvc

Swedish Advertising Ombudsman 2015 About http://bit.ly/1snrgvc accessed 15 August 2015

WASPA 2015 http://bit.ly/1TTTplZ

Wireless Application Service Providers' Association 2015 About WASPA http://bit.ly/1TTTplZ accessed 20 June 2015 
WASPA 2016 http://bit.ly/1TdFqoN

Wireless Application Service Providers' Association 2016 The WASPA Code of Conduct http://bit.ly/1TdFqoN accessed 1 February 2016

WASPA $2016 \mathrm{http}: / /$ bit.ly/24SdG0p

Wireless Application Service Providers' Association 2016 WASPA Constitution http://bit.ly/24SdG0p accessed 1 February 2016

\section{List of Abbreviations}

AJLP

ASA Code

ASASA

CAP

CAP Code

CLP

CPA

EASA

EJCL

IARN

ICC

ICC Code

JAR

JCP

JLS

JPM

L\&P

MCA

MLR

OJLS

PCP

U Pa J Int'I Bus L

VAT

WASPA

WASPA Code
Australian Journal of Legal Philosophy

Code of Advertising Practice of the Advertising Standards Authority of South Africa

Advertising Standards Authority of South Africa

Committee of Advertising Practice (United Kingdom)

United Kingdom Code of Non-Broadcast Advertising,

Sales Promotion and Direct Marketing

Current Legal Problems

Consumer Protection Act 68 of 2008

European Advertising Standards Alliance

Electronic Journal of Comparative Law

International Audiotex Regulators Network

International Chamber of Commerce

International Chamber of Commerce: Consolidated

Code of Advertising and Marketing Communications

Practice

Journal of Advertising Regulation

Journal of Consumer Policy

Journal of Law and Society

Journal of Promotion Management

Law and Policy

Marketing Code Authority

Modern Law Review

Oxford Journal of Legal Studies

PhonepayPlus Code of Practice

University Pennsylvania Journal of International

Business Law

Value-Added Tax

Wireless Application Service Providers' Association

Code of Conduct of the Wireless Application Service

Providers' Association 